\title{
Erratum to: Anticancer Activities of the Methanolic Extract from Lemon Leaves in Human Breast Cancer Stem Cells
}

\author{
Jeong Yong Moon • Linh Thi Thao Nguyen · Ho Bong Hyun · Ahmed Osman • \\ Minwhan Cho · Suyeong Han • Dong-Sun Lee* - Kwang Seok Ahn*
}

Published online: 31 December 2015

(C) The Korean Society for Applied Biological Chemistry 2015

Erratum to: J Appl Biol Chem (2015) 58, 219-226

DOI 10.3839/jabc.2015.034

\section{p. 219}

It will be deleted the Minwhan Cho · Suyeong Han · Dong-Sun Lee* and added the Somi Kim Cho* from the author list.

The online version of the original article can be found under doi: $10.3839 /$ jabc.2015.034

Jeong Yong Moon · Linh Thi Thao Nguyen · Ho Bong Hyun · Ahmed Osman · Kwang Seok Ahn* Somi Kim Cho*

J. Y. Moon and L. T. T. Nguyen contributed equally.

J. Y. Moon

Subtropical Horticulture Research Institute, Jeju National University, Jeju 690-756, Republic of Korea

L. T. T. Nguyen · H. B. Hyun

Faculty of Biotechnology, College of Applied Life Sciences, SARI, Jeju

National University, Jeju 690-756, Republic of Korea

A. Osman

Faculty of Advanced Convergence Technology \& Science, Jeju National University, Jeju, 690-756, Republic of Korea

\section{K. S. Ahn}

Department of Oriental Pathology, College of Oriental Medicine, Kyung

Hee University, Seoul 130-701, Republic of Korea

\section{S. K. Cho}

Subtropical Horticulture Research Institute, Jeju National University, Jeju 690-756, Republic of Korea

Faculty of Biotechnology, College of Applied Life Sciences, SARI, Jeju National University, Jeju 690-756, Republic of Korea

*Corresponding author (K. S. Ahn: ksahn@khu.ac.kr;

S. K. Cho: somikim@jejunu.ac.kr)

This is an Open Access article distributed under the terms of the Creative Commons Attribution Non-Commercial License (http://creativecommons. org/licenses/by-nc/3.0/) which permits unrestricted non-commercial use, distribution, and reproduction in any medium, provided the original work is properly cited. 